\title{
Adel og proletariat i norsk helsevesen
}

\author{
Alle foreldres mareritt er at deres \\ barn blir syke. To av våre døtre ble \\ alvorlig syke i samme alder. Vi har \\ erfart store - altfor store - for- \\ skjeller i deres møte med helse- \\ vesenet.
}

Vår mellomste datter fikk diagnosen kronisk utmattelsessyndrom/myalgisk encefalopati (CFS/ME) som 18-åring, etter et slitsomt år med en mistroisk fastlege og en lang vandring mellom spesialister hvis bord det ikke var. Behandlingstilbud fantes ikke. Hun lå i 16 måneder, ble forferdelig tynn og sliten, men ble langsomt bedre de neste åtte årene. Hun har behandlet seg selv kosthold, kognitiv terapi, redusert og svært målbevisst aktivitet. Vi vet ikke om dette har hjulpet direkte, naturligvis, men hun har med stor selvdisiplin kunnet ta styring over egen utvikling og returnere til et tilnærmet normalt liv.

Vår yngste datter fikk diagnosen Hodgkins lymfom som 18-åring. Fastlegen fattet mistanke, Ullevål stilte kjapt diagnosen og overførte henne til Radiumhospitalet. Behandling startet øyeblikkelig, med et samkjørt og godt kommuniserende sykehus som fulgte opp ikke bare pasienten, men også de pårørende. Det ble cellegift, tilbakefall året etter, og autonom stamcelletransplantasjon. Nå har hun vært kreftfri i to år.

Og vår ME-pasient har endelig fått tilbud om psykologhjelp - ikke på grunn av sin sykdom, men fordi lillesøster fikk kreft.

Hvorfor slikt adelskap og proletariat blant pasienter? Jeg mener det ligger i sykdommenes dramaturgi, legenes hverdag og helsevesenets organisering.
Kreftens dramaturgi er tydelig: Det er liten tvil om at man er syk, den kommer raskt, er (for unge voksne) tydelig uforskyldt og alvorlig. Behandling finnes som regel, med gode, men ikke sikre prognoser. CSF/ME er en uklar sykdom, en utelukkelsesdiagnose, med ukjente årsaker og ingen forskningsbasert effektiv behandling. Sykdommen tilskrives gjerne egen atferd (som magesår før Marshall \& Warren) og avskrives av mange leger som «diffusitas». Ofrene er verken synlige eller taleføre og ivaretas primært av nære pårørende. Blir de friske, risikerer de beskyldninger om ikke å ha hatt sykdommen av pasientgrupper som er nærmest sykelig opptatt av at tilstanden ikke har psykiske faktorer.

Legenes hverdag er preget av stort arbeidspress og et konstant krav til problemløsning. Som alle andre har leger behov for å se resultater av det de gjør. Størst opplevd effekt får man med alvorlige sykdommer der forskningen - og dermed tilgjengelige verktøy - er forbi et preparadigmatisk stadium. Det er rett og slett mindre tilfredsstillende å arbeide med diagnoser som CSF/ME: Uklare sykdommer uten tydelige markører, som krever bred kompetanse fra mange spesialiteter og der det ikke er hjelp å få fra avansert utstyr og fasiliteter. Om og når ME får en entydig diagnostisk markør, vil bildet helt sikkert endre seg.

Problemet med helsevesenets organisering er mer komplisert. I teorien skal helsevesenet løse problemer ved å utvikle og kombinere spesialkompetanser rundt en pasient. Så lenge pasienten lsom kan vurdere koordinering, men ikke spesialiseringsdybde) ikke betaler selv, er man flinkere til å spesialisere enn til å kombinere behand- ling på tvers av faglige og byråkratiske kategorier. (Kvakksalvere satser på pasientobserverbare duftlys og holisme i mangel av reelle spesialkunnskaper). Å overføre makt fra spesialister til generalister er god teori, men vanskelig praksis.

Hva kan gjøres? Holdningsendringer tar tid. Man kan budsjettere ressurser ut fra problem heller enn løsning, sentralisere fagmiljøer, å fjerne de for et bitte lite land meningsløse helseregionene og tvinge igjennom felles registre og bedre bruk av koordinerende teknologi. Pasientene skal slippe å bruke krefter på å fortelle sin sykehistorie om og om igjen.

Rent helseøkonomisk burde CSF/ME være like viktig som kreft for unge voksne, siden flere i denne aldersgruppen rammes. Kreft er på noen måter enkelt: du vet at du er syk (og blir trodd), du blir frisk (muligens med senskader), eller du dør. CSF/ME tar ikke livet av deg, men tar livet fra deg. Vår mellomste datter anser seg selv som frisk, men har større begrensninger i fremtidig livsutfoldelse enn vår yngste, senskader eller ikke.

Adelskap forplikter, og jeg har oppfordret Kreftforeningen til å bruke ressurser også på CSF/ME, blant annet fordi friskmeldte unge kreftpasienter har høyere risiko for å utvikle slike tilstander. Skulle så skje, blir de i alle fall trodd.

De omtalte har gitt samtykke til at artikkelen blir publisert.

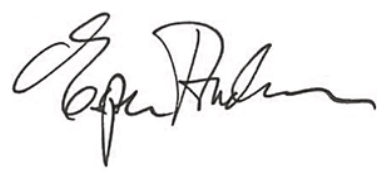

